\title{
Maximizing Yield and Water Use Efficiency of Wheat Crop Using Drip Irrigation Systems
}

\author{
J.N. Lokhande ${ }^{1 *}$, M.M. Deshmukh ${ }^{1}$, Bal Krishna ${ }^{2}$ and S.B. Wadatkar ${ }^{1}$ \\ ${ }^{1}$ Department of Irrigation and Drainage Engineering, Dr. Panjabrao Deshmukh Krishi \\ Vidyapeeth, Akola-444104 (MS), India \\ ${ }^{2}$ Jain Irrigation Systems LTD, Jain Hills, Jalgaon-425001 (MS), India
}

*Corresponding author

\section{A B S T R A C T}

\begin{tabular}{|c|}
\hline Keywords \\
\hline $\begin{array}{l}\text { Surface and } \\
\text { subsurface drip } \\
\text { irrigation method, } \\
\text { Water use } \\
\text { efficiency, Latera } \\
\text { and emitter } \\
\text { spacings, Water } \\
\text { saving }\end{array}$ \\
\hline Article Info \\
\hline $\begin{array}{l}\text { Accepted: } \\
\text { 20 June } 2019 \\
\text { Available Online } \\
10 \text { July } 2019\end{array}$ \\
\hline
\end{tabular}

Rapid urbanization and industrialization have increased the pressure on limited existing fresh water to meet the growing needs for food production. To immediate responses to this challenge is the efficient use of irrigation technology. Drip irrigation methods may play an important role in efficient use of water but there is still limited information on their use on wheat crops. An experiment was conducted in Split-split plot design to evaluate the effects of irrigation method under different lateral and emitter spacing on wheat yield, and irrigation water use efficiency (IWUE). The irrigation methods investigated were surface drip, subsurface drip and check basin irrigation. The highest wheat yield (64.31 $\left.\mathrm{qha}^{-1}\right)$ and IWUE (1.58 $\mathrm{q} / \mathrm{ha}-\mathrm{cm})$ was obtained using treatment combination surface drip irrigation and $60 \mathrm{~cm}$ lateral spacing with $20 \mathrm{~cm}$ emitter spacing and the lowest yield of wheat crop (31.46 $\left.\mathrm{qha}^{-1}\right)$ and irrigation water use efficiency $(0.52 \mathrm{q} / \mathrm{ha}$ $\mathrm{cm})$ was obtained using check basin irrigation method. In subsurface drip irrigation highest yield and IWUE in wheat yield production $\left(50.70 \mathrm{qha}^{-1}\right.$ and 1.25 $\mathrm{q} / \mathrm{ha}-\mathrm{cm}$ ) in $60 \mathrm{~cm}$ lateral spacing with $20 \mathrm{~cm}$ emitter spacing. Using surface drip irrigation with $60 \mathrm{~cm}$ lateral spacing with $20 \mathrm{~cm}$ emitter spacing can save $32.96 \%$ of irrigation water with increasing yield of wheat crop.

\section{Introduction}

Agriculture is the largest user of fresh water; this water is under severe competition with industry, energy, domestic and other sectors. Per capita availability of fresh water is also decreasing and is projected to go below the scarcity level for human and livestock sustenance in future. Hence, water is a precious national asset and there are several concerns regarding water resources in the country. Enhancing crop water use efficiency is the need of the time. At the same time, enhancing crop productivity to increase irrigation water use efficiency is very essential with saving of irrigation water. To meet this challenge, micro-irrigation is the most potential option for saving of irrigation water 
and enhancing irrigation water use efficiency. The use of drip irrigation alone can increase the crop yields significantly over surface and sprinkler irrigation systems (Tiwari et al., 1998).Surface drip irrigation and subsurface drip irrigation (SDI) can be a viable alternative when water is limited or when the irrigation capacity is insufficient with traditional methods. As a general rule, drip line spacing is a multiple of the crop row spacing, whereas emitter spacing is usually related to the plant spacing along the row. Providing the crop with equal or nearly equal opportunity to the applied water should be the goal of all drip designs. The design process should carefully match emitter discharge and emitter spacing to the soil hydraulic characteristics in order to avoid problems such as backpressure and water surfacing that can occur with improper design.

Emitter spacing and lateral spacing is a system design characteristic and should be selected taking into account the soil water properties of the site. The goal of research is to evaluate the effect of different emitter and lateral spacing on wheat yield and irrigation water use efficiency in surface and subsurface drip irrigation.

\section{Materials and Methods}

A two years experiment was carried out during rabi seasons of 2016-17 and 2017-18 to study the effect of different lateral and emitter spacing on yield and water use efficiency of wheat under surface and subsurface drip irrigation system.

\section{Experimental and soil description}

The research work was carried out at Jain HiTech Agri. Institute, Jain Irrigation Systems Ltd., Jalgaon, Maharashtra, Soils of the experimental site were classified silty clay loam with the field capacity ranging from 31 to $32 \%$. In order to achieve the objectives of the study, three irrigation methods were investigated "drip irrigation method (Surface and subsurface) and check basin method of irrigation" the wheat variety AKAW - 4210-6. (PDKV Sardar) was used in the experiment.

\section{Experimental design and irrigation water requirement}

A field experiment Split-split plot design with eighteen treatments was carried with one control treatment as check basin (traditional) irrigation method along with three replications. The experiment comprised of three factors; (i) Surface $\left(\mathrm{S}_{1}\right)$ and subsurface drip irrigation methods $\left(\mathrm{S}_{2}\right)$ (ii) $60 \mathrm{~cm}\left(\mathrm{~L}_{1}\right), 80$ $\mathrm{cm}\left(\mathrm{L}_{2}\right), 100 \mathrm{~cm}\left(\mathrm{~L}_{3}\right)$ lateral spacing (iii) 20 $\mathrm{cm}\left(\mathrm{E}_{1}\right), 30 \mathrm{~cm}\left(\mathrm{E}_{2}\right), 40 \mathrm{~cm}\left(\mathrm{E}_{3}\right)$ emitter spacing. In subsurface drip irrigation lateral buried at $20 \mathrm{~cm}$ depth.

Inorganic fertilizers were applied in all the plots with the recommended doses of $120 \mathrm{~N}$, $60 \mathrm{P}_{2} \mathrm{O}_{5}$ and $60 \mathrm{~K} \mathrm{kgha}{ }^{-1}$. Half of the recommended dose of nitrogen and all of the phosphorus and potash were applied at the time of sowing through broadcasting, while the remaining half dose $\mathrm{N}$ was applied after 21 days after sowing and remaining $\mathrm{N}$ was applied at 42 days after sowing using watersoluble fertilizers. In this study, AKAW 42106 (PDKV Sardar) was used. The seeds were sown on 30 November 2016in the first year and on 23 November 2017 in the second year of study and harvested 4 March 2017, 1 March 2018 during first and second year of the study respectively.

\section{Computation of irrigation water requirement}

Water requirement of wheat crop under surface and subsurface drip irrigation system was calculated by using following formulae (Michael, 2008). 
$\mathrm{V}=\mathrm{E}_{\mathrm{pan}} \mathrm{x} \mathrm{K}_{\mathrm{p}} \mathrm{x} \mathrm{K}_{\mathrm{c}} \mathrm{x} \mathrm{A}(1)$

Where,

V - Volume of Irrigation water requirement per plot (lit)

$E_{p a n}$ - Cumulative evaporation for two days $(\mathrm{mm})$

$\mathrm{K}_{\mathrm{p}}$ - Pan coefficient $(0.8)$

$\mathrm{K}_{\mathrm{c}}$ - Crop coefficient

A - Area allotted per plot $\left(\mathrm{m}^{2}\right)$

Wheat crop was irrigated through surface and subsurface drip irrigation system as per crop water requirement alternate day.

In check basin method of irrigation, six irrigations were scheduled at six critical growth stages of wheat crop, viz. crown root initiation (CRI), maximum tillering, late jointing, flowering, milking stage, and dough stage.

In this treatment, depth of irrigation was determined by observing actual soil moisture before every irrigation and using following equation (Michael 2008)

$\mathrm{D}=\frac{M_{f c}-M_{b i}}{100} \times \mathrm{\gamma} \times \mathrm{Z} \times 1000$

Where,

D - Depth of Irrigation water, (mm)

$\mathrm{M}_{\mathrm{fc}}$-Moisture content at field capacity, (32.37 $\%)$

$\mathrm{M}_{\mathrm{bi}}$ - Moisture content before irrigation, (\%)

Y - Bulk density, $\left(\mathrm{gm} \mathrm{cm}^{-3}\right)$

$\mathrm{Z}$ - Effective root zone depth, (0.60 m).
First common irrigation was given to all the treatments just after sowing to bring the experimental plots to field capacity.

For this purpose soil moisture content was determined before sowing to calculate the depth of first common irrigation.

\section{Observations recorded}

Various observations were recorded according to pre-harvest observations, post-harvest observations and yield parameters. Immediately after crop establishment, five plants were randomly selected from each plot was used for recording plant height $(\mathrm{cm})$, flag leaf area $\left(\mathrm{cm}^{2}\right)$, number of effective tillers per square metre, number of grains per earhead, 1000-grain weight or test weight (gm), grain yield $\left(\mathrm{q} \mathrm{ha} \mathrm{h}^{-1}\right)$ and straw yield $\left(\mathrm{q} \mathrm{ha} \mathrm{h}^{-1}\right)$. Plant height was recorded at 30 and 60 days after sowing and at the time of harvest all other observations were recorded at the time of harvest.

Computation of irrigation water use efficiency

Irrigation water use efficiency is the ratio of crop yield to the amount of irrigation water applied in the field.

It was calculated by using an equation (Michael 2008)

WUE $=\frac{\mathrm{Y}}{\mathrm{WR}}$

Where,

IWUE - Irrigation water use efficiency, qha ${ }^{1} \mathrm{~cm}^{-1}$

Y - Crop yield, q

WR - Water requirement ha-cm 


\section{Statistical analysis}

The data of field experiment for both the year 2016-17 and 2017-18 were collected for each treatment and replication, the mean value of those on plant growth, yield attribute and yield were subjected to Split-split plot design for the statistical analysis to assess the test of significance for both individual year and pooled analysis.

\section{Results and Discussion}

The results obtained from this study will be presented and discussed as follows:

\section{Growth Contributing Parameters}

Effect of irrigation methods i.e. surface drip irrigation and subsurface drip irrigation on plant height at the time of harvest and flag leaf area was found non-significant in pooled mean analysis.

The significantly maximum vegetative growth in terms of plant height, flag leaf area was recorded under $60 \mathrm{~cm}$ lateral spacing and 20 $\mathrm{cm}$ emitter spacing. The treatment combination surface drip irrigation with $60 \mathrm{~cm}$ lateral spacing recorded the significantly maximum values of plant height. The significantly maximum values of flag leaf area were found in subsurface drip irrigation with $60 \mathrm{~cm}$ lateral spacing. The interaction effect of irrigation methods and emitter spacing on plant height and flag leaf area were found nonsignificant. The interaction effects of lateral and emitter spacings on plant height and flag leaf area were also found non-significant. The treatment combination $60 \mathrm{~cm}$ lateral spacing with $20 \mathrm{~cm}$ emitter spacing recorded the numerically maximum values of plant height and flag leaf area. There was non-significant difference found in treatment combination with irrigation methods, lateral and emitter spacings.
Comparing irrigation methods, lowest values of plant height and flag leaf area are recorded in check basin method of irrigation comparing to surface and subsurface drip irrigation similar results were recorded by Dilip and Madakini, (1993).Favourable soil moisture without wide fluctuations under drip irrigation treatments might have stimulated increased activity of meristematic cells and cell elongation of internodes resulting in a higher growth rate of stem in turn promoting the increased plant height and flag leaf area of wheat as compared to check basin method of irrigation.

\section{Yield Contributing Parameters}

Effect of irrigation methods i.e. surface drip irrigation and subsurface drip irrigation on number of effective tillers, number of grains per earhead and 1000 grain weight was found non-significant in pooled mean analysis.

Significantly maximum values of the number of effective tillers per square metre, number of grains per earhead and 1000 grain weight were recorded in $60 \mathrm{~cm}$ lateral spacing. $20 \mathrm{~cm}$ emitter spacing recorded significantly maximum value of number of effective tillers per square metre, number of grains per earhead and 1000 grain weight. Treatment combination surface drip irrigation with $60 \mathrm{~cm}$ lateral spacing recorded significantly high value of number of effective tillers followed by subsurface drip irrigation with $60 \mathrm{~cm}$ lateral spacing. These findings are consistent with the results reported by Wang et al., (2013 $a, b)$. The interaction effects of irrigation methods and lateral spacings on number of grains per earhead were found non-significant. The treatment combination surface drip irrigation with $60 \mathrm{~cm}$ lateral spacing recorded numerically maximum number of grains per earhead. Significantly maximum value of 1000 grain weight was found in treatment combination subsurface drip irrigation with 60 
$\mathrm{cm}$ lateral spacing. Effect of irrigation methods and emitter spacings on number of effective tillers, number of grains per earhead were found non-significant. Significantly highest value of 1000 grain weight was recorded in surface drip irrigation with $20 \mathrm{~cm}$ emitter spacing. The interaction effects of lateral and emitter spacings on number of effective tillers and 1000 grain weight were found non-significant. Significantly highest value of number of grains per earhead recorded in $60 \mathrm{~cm}$ lateral spacing with $20 \mathrm{~cm}$ emitter spacing. Non-significant difference were recorded for number of effective tillers per square metre, number of grains per earhead and 1000 grain weight due to treatment combination of irrigation method, different lateral and emitter spacings.

These results are harmony with results obtained by Wang et al., (2013 a,b), Rao et al., (2016)indicated that closer lateral and emitter spacing enhanced yield contributing parameters which results in maximum grain yield of wheat

Comparing to check basin method of irrigation with surface and subsurface drip irrigation for number of effective tillers, number of grains per earhead and 1000 grain weight lowest values were recorded in check basin method of irrigation.

\section{Yield and Straw yield}

Effect of irrigation methods i.e. surface drip irrigation and subsurface drip irrigation on grain and straw yield were found nonsignificant as presented in Table 1.

Significantly maximum value of grain yield was recorded in treatment $60 \mathrm{~cm}$ lateral spacing. $20 \mathrm{~cm}$ emitter spacing recorded significantly maximum value of grain yield. Treatment combination surface drip irrigation with $60 \mathrm{~cm}$ lateral spacing recorded significantly highest value of grain yield. The interaction effects of irrigation methods and emitter spacings on grain yield were nonsignificant. Treatment combination $60 \mathrm{~cm}$ lateral spacing with $20 \mathrm{~cm}$ emitter spacing was recorded significantly maximum grain yield followed by subsurface drip irrigation with 60 $\mathrm{cm}$ lateral spacing as shown in Table 2.

Similar results were recorded by Chouhan et al., (2015). Non-significant difference was found on grain yield due to interaction effects of irrigation methods, different lateral spacings and emitter spacings. Wider lateral spacing (i.e. $100 \mathrm{~cm}$ lateral spacing) may have exposed the crop to non-uniform moisture distribution at reproductive phase, which might have pulled down the number of effective tillers per square meter and subsequently grain yield as compared to 60 $\mathrm{cm}$ and $80 \mathrm{~cm}$ lateral spacing. Similar results have been reported by Arafa et al., (2009).

Comparing to check basin with surface and subsurface drip irrigation method lowest grain yield was recorded in check basin irrigation method as shown in Table 1 and 3.

In respect of character straw yield, the nonsignificant results were recorded in the effect of lateral spacings, emitter spacings, interaction effects of irrigation methods with lateral spacings, interaction effects of irrigation methods with emitter spacings, effect of lateral spacings and emitter spacings and effect of irrigation methods with lateral spacings and emitter spacings. Numerically maximum value of straw yield was observed in $60 \mathrm{~cm}$ lateral spacing.

Comparing to check basin irrigation method with surface and subsurface drip irrigation lowest value of straw yield was recorded in check basin method of irrigation. Similar results reported by Hemlata (2015) under drip irrigated rice. 
Table.1 Effect of irrigation methods and different lateral and emitter spacings on grain and straw yield of wheat crop

\begin{tabular}{|c|c|c|c|c|c|c|}
\hline \multirow{2}{*}{$\begin{array}{c}\text { Treatment } \\
\text { Irrigation methods } \\
\text { (S) }\end{array}$} & \multicolumn{3}{|c|}{ Grain yield $\left(q\right.$ ha $\left.^{-1}\right)$} & \multicolumn{3}{|c|}{ Straw yield $\left(q\right.$ ha $\left.^{-1}\right)$} \\
\hline & 2016-17 & 2017-18 & Pooled mean & 2016-17 & 2017-18 & Pooled mean \\
\hline $\mathrm{S}_{1}$ & 39.40 & 42.08 & 40.74 & 87.05 & 83.80 & 87.44 \\
\hline $\mathbf{S}_{2}$ & 41.09 & 43.08 & 42.08 & 87.38 & 84.95 & 87.45 \\
\hline $\mathrm{SE}(\mathbf{m}) \pm$ & 1.63 & 1.11 & 1.3 & 1.433 & 0.79 & 1.16 \\
\hline CD at $5 \%$ & NS & NS & NS & $\mathrm{NS}$ & NS & NS \\
\hline \multicolumn{7}{|l|}{ Lateral spacing (L) } \\
\hline $\mathbf{L}_{1}$ & 46.40 & 50.42 & 48.41 & 88.57 & 87.44 & 88.71 \\
\hline $\mathbf{L}_{2}$ & 38.19 & 40.51 & 39.35 & 86.97 & 83.66 & 87.11 \\
\hline $\mathbf{L}_{3}$ & 36.15 & 36.80 & 36.47 & 86.11 & 82.03 & 86.53 \\
\hline $\mathrm{SE}(\mathrm{m}) \pm$ & 1.199 & 1.845 & 1.22 & 1.845 & 1.454 & 1.743 \\
\hline CD at $5 \%$ & 3.905 & 6.01 & 3.974 & NS & NS & NS \\
\hline \multicolumn{7}{|l|}{ Emitter spacing (E) } \\
\hline $\mathbf{E}_{1}$ & 43.96 & 48.87 & 46.42 & 88.36 & 88.12 & 88.52 \\
\hline $\mathbf{E}_{2}$ & 40.14 & 42.34 & 41.24 & 87.44 & 84.99 & 87.49 \\
\hline $\mathbf{E}_{3}$ & 36.63 & 36.51 & 36.57 & 85.85 & 80.01 & 86.32 \\
\hline $\mathrm{SE}(\mathbf{m}) \pm$ & 1.107 & 1.352 & 0.969 & 1.167 & 2.393 & 1.111 \\
\hline CD at $5 \%$ & 3.231 & 3.948 & 2.830 & NS & NS & NS \\
\hline
\end{tabular}

Table.2 Interaction effect of irrigation methods with different lateral and emitter spacings on grain and straw yield of wheat crop

\begin{tabular}{|c|c|c|c|c|c|c|}
\hline \multirow{2}{*}{$\begin{array}{c}\text { Treatment } \\
\text { Interaction }(\mathrm{SXL})\end{array}$} & \multicolumn{3}{|c|}{ Grain yield $\left(q\right.$ ha $\left.^{-1}\right)$} & \multicolumn{3}{|c|}{ Straw yield $\left(\mathrm{q} \mathrm{ha}^{-1}\right)$} \\
\hline & 2016-17 & 2017-18 & $\begin{array}{c}\text { Pooled } \\
\text { mean }\end{array}$ & 2016-17 & 2017-18 & $\begin{array}{c}\text { Pooled } \\
\text { mean }\end{array}$ \\
\hline$S_{1} L_{1}$ & 50.56 & 53.26 & 51.91 & 87.44 & 86.59 & 88.34 \\
\hline $\mathbf{S}_{1} \mathbf{L}_{2}$ & 34.68 & 37.86 & 36.27 & 87.31 & 82.11 & 87.53 \\
\hline $\mathbf{S}_{1} \mathbf{L}_{3}$ & 32.97 & 35.11 & 34.04 & 86.01 & 82.71 & 86.46 \\
\hline $\mathbf{S}_{2} \mathbf{L}_{1}$ & 42.23 & 47.58 & 44.90 & 89.30 & 88.29 & 89.07 \\
\hline $\mathbf{S}_{2} \mathbf{L}_{2}$ & 41.71 & 43.16 & 42.43 & 86.63 & 85.21 & 86.69 \\
\hline $\mathbf{S}_{2} \mathbf{L}_{3}$ & 39.32 & 38.49 & 38.91 & 86.21 & 81.36 & 86.60 \\
\hline $\mathrm{SE}(\mathbf{m}) \pm$ & 1.696 & 2.609 & 1.725 & 2.609 & 2.057 & 2.465 \\
\hline CD at $5 \%$ & 5.905 & NS & 5.620 & NS & NS & NS \\
\hline \multicolumn{7}{|l|}{ Interaction (SXE) } \\
\hline$S_{1} E_{1}$ & 43.13 & 49.17 & 46.15 & 87.77 & 88.20 & 88.88 \\
\hline $\mathbf{S}_{1} \mathbf{E}_{2}$ & 39.01 & 41.65 & 40.36 & 87.78 & 86.14 & 87.39 \\
\hline $\mathbf{S}_{1} \mathbf{E}_{3}$ & 36.02 & 35.41 & 35.71 & 85.61 & 77.06 & 86.06 \\
\hline $\mathbf{S}_{2} \mathbf{E}_{1}$ & 44.79 & 48.58 & 46.69 & 88.95 & 88.04 & 88.17 \\
\hline $\mathbf{S}_{\mathbf{2}} \mathbf{E}_{2}$ & 41.21 & 43.03 & 42.12 & 87.09 & 83.84 & 87.59 \\
\hline $\mathbf{S}_{2} \mathbf{E}_{3}$ & 37.25 & 37.62 & 37.44 & 86.09 & 82.97 & 86.59 \\
\hline $\mathrm{SE}(\mathbf{m}) \pm$ & 1.565 & 1.912 & 1.371 & 1.651 & 3.384 & 1.571 \\
\hline CD at $5 \%$ & NS & NS & NS & NS & NS & NS \\
\hline
\end{tabular}


Table.3 Interaction effect of different lateral and emitter spacings on grain and straw yield of wheat crop

\begin{tabular}{|c|c|c|c|c|c|c|}
\hline Treatment & \multicolumn{3}{|c|}{ Grain yield $\left(q h^{-1}\right)$} & \multicolumn{3}{|c|}{ Straw yield $\left(q\right.$ ha $\left.^{-1}\right)$} \\
\hline Interaction (LXE) & 2016-17 & $2017-18$ & Pooled mean & 2016-17 & 2017-18 & Pooled mean \\
\hline $\mathbf{L}_{1} \mathbf{E}_{1}$ & 53.79 & 61.21 & 57.50 & 88.95 & 90.98 & 88.36 \\
\hline $\mathbf{L}_{1} \mathbf{E}_{2}$ & 45.28 & 49.92 & 47.60 & 88.81 & 88.44 & 89.48 \\
\hline $\mathbf{L}_{1} \mathbf{E}_{3}$ & 40.12 & 40.12 & 40.12 & 87.95 & 82.89 & 88.28 \\
\hline $\mathbf{L}_{2} \mathbf{E}_{1}$ & 38.82 & 44.11 & 41.46 & 88.72 & 85.80 & 88.64 \\
\hline $\mathbf{L}_{2} \mathbf{E}_{2}$ & 40.59 & 41.57 & 41.08 & 86.67 & 83.24 & 86.67 \\
\hline $\mathbf{L}_{2} \mathbf{E}_{3}$ & 35.17 & 35.85 & 35.51 & 85.52 & 81.93 & 86.02 \\
\hline $\mathbf{L}_{3} \mathbf{E}_{1}$ & 39.27 & 41.31 & 40.29 & 87.41 & 87.59 & 88.58 \\
\hline $\mathbf{L}_{3} \mathbf{E}_{2}$ & 34.56 & 35.54 & 35.05 & 86.83 & 83.30 & 86.33 \\
\hline $\mathbf{L}_{3} \mathbf{E}_{3}$ & 34.62 & 33.56 & 34.09 & 84.09 & 75.22 & 84.68 \\
\hline $\mathrm{SE}(\mathrm{m}) \pm$ & 1.917 & 2.342 & 1.679 & 2.021 & 4.144 & 1.929 \\
\hline CD at $5 \%$ & 5.596 & 6.838 & 4.901 & NS & NS & NS \\
\hline \multicolumn{7}{|l|}{ Interaction SXLXE } \\
\hline $\mathrm{SE}(\mathbf{m}) \pm$ & 2.711 & 3.312 & 2.374 & 2.859 & 5.86 & 2.72 \\
\hline CD at $5 \%$ & NS & NS & NS & NS & NS & NS \\
\hline Control & 32.31 & 27.61 & 29.96 & 78.67 & 81.41 & 80.04 \\
\hline
\end{tabular}

Table.4 Irrigation water use efficiency of wheat as influenced by different irrigation methods, lateral and emitter spacings during 2016-17 and 2017-18

\begin{tabular}{|c|c|c|c|c|c|c|c|c|c|}
\hline \multirow[t]{2}{*}{ Treatment } & \multicolumn{3}{|c|}{ Yield of wheat $\left(\mathrm{q} \mathrm{ha}^{-1}\right)$} & \multicolumn{3}{|c|}{$\begin{array}{c}\text { Irrigation water } \\
\text { requirement (ha-cm) }\end{array}$} & \multicolumn{3}{|c|}{$\begin{array}{l}\text { Irrigation water use } \\
\text { efficiency }\left(\mathbf{q ~ h a} \mathbf{~ h}^{-1} \mathbf{c m}^{-1}\right)\end{array}$} \\
\hline & $\begin{array}{c}2016- \\
17\end{array}$ & $\begin{array}{c}2017- \\
18\end{array}$ & $\begin{array}{c}\text { Pooled } \\
\text { mean }\end{array}$ & $\begin{array}{c}2016- \\
17\end{array}$ & $\begin{array}{l}2017- \\
18\end{array}$ & $\begin{array}{l}\text { Pooled } \\
\text { mean }\end{array}$ & $\begin{array}{c}2016- \\
17\end{array}$ & $\begin{array}{l}2017- \\
18\end{array}$ & $\begin{array}{l}\text { Pooled } \\
\text { mean }\end{array}$ \\
\hline $\mathbf{T}_{1}-\mathbf{S}_{1} \mathbf{L}_{1} \mathbf{E}_{1}$ & 60.26 & 68.35 & 64.31 & 43.87 & 37.04 & 40.45 & 1.37 & 1.85 & 1.58 \\
\hline$T_{2}-S_{1} L_{1} E_{2}$ & 49.02 & 52.72 & 50.87 & 43.87 & 37.04 & 40.45 & 1.12 & 1.42 & 1.25 \\
\hline $\mathbf{T}_{3}-\mathbf{S}_{1} \mathbf{L}_{1} \mathbf{E}_{3}$ & 42.43 & 32.72 & 40.57 & 43.87 & 37.04 & 40.45 & 0.97 & 1.05 & 1.00 \\
\hline $\mathbf{T}_{4}-\mathbf{S}_{1} \mathbf{L}_{2} \mathbf{E}_{1}$ & 34.33 & 41.31 & 37.82 & 43.87 & 37.04 & 40.45 & 0.78 & 1.12 & 0.93 \\
\hline $\mathbf{T}_{5}-\mathbf{S}_{1} \mathbf{L}_{2} \mathbf{E}_{2}$ & 35.39 & 37.94 & 36.67 & 43.87 & 37.04 & 40.45 & 0.81 & 1.02 & 0.90 \\
\hline$T_{6}-S_{1} L_{2} E_{3}$ & 34.33 & 34.33 & 34.33 & 43.87 & 37.04 & 40.45 & 0.78 & 0.93 & 0.84 \\
\hline$T_{7}-S_{1} L_{3} E_{1}$ & 34.80 & 37.85 & 36.32 & 43.87 & 37.04 & 40.45 & 0.79 & 1.02 & 0.89 \\
\hline$T_{8}-S_{1} L_{3} E_{2}$ & 32.83 & 34.31 & 33.57 & 43.87 & 37.04 & 40.45 & 0.75 & 0.93 & 0.82 \\
\hline $\mathbf{T}_{9}-\mathbf{S}_{1} \mathbf{L}_{3} \mathbf{E}_{3}$ & 31.30 & 33.19 & 32.24 & 43.87 & 37.04 & 40.45 & 0.71 & 0.90 & 0.79 \\
\hline $\mathbf{T}_{10^{-}}-\mathbf{S}_{2} \mathbf{L}_{1} \mathbf{E}_{1}$ & 47.33 & 54.07 & 50.70 & 43.87 & 37.04 & 40.45 & 1.08 & 1.46 & 1.25 \\
\hline $\mathbf{T}_{11}-\mathbf{S}_{2} \mathbf{L}_{1} \mathbf{E}_{2}$ & 41.56 & 47.13 & 44.34 & 43.87 & 37.04 & 40.45 & 0.95 & 1.27 & 1.09 \\
\hline$T_{12}-S_{2} L_{1} E_{3}$ & 37.81 & 41.54 & 39.68 & 43.87 & 37.04 & 40.45 & 0.86 & 1.12 & 0.98 \\
\hline $\mathbf{T}_{13}-\mathbf{S}_{2} \mathbf{L}_{2} \mathbf{E}_{1}$ & 43.31 & 46.91 & 45.11 & 43.87 & 37.04 & 40.45 & 0.99 & 1.27 & 1.11 \\
\hline $\mathbf{T}_{14}-\mathrm{S}_{2} \mathbf{L}_{2} \mathbf{E}_{2}$ & 45.80 & 45.20 & 45.50 & 43.87 & 37.04 & 40.45 & 1.04 & 1.22 & 1.12 \\
\hline $\mathbf{T}_{15}-\mathbf{S}_{2} \mathbf{L}_{2} \mathbf{E}_{3}$ & 36.02 & 37.39 & 36.70 & 43.87 & 37.04 & 40.45 & 0.82 & 1.01 & 0.90 \\
\hline$T_{16}-S_{2} L_{3} E_{1}$ & 43.74 & 44.78 & 44.26 & 43.87 & 37.04 & 40.45 & 1.00 & 1.21 & 1.09 \\
\hline $\mathbf{T}_{17}-\mathbf{S}_{2} \mathbf{L}_{3} \mathbf{E}_{2}$ & 36.30 & 36.78 & 36.54 & 43.87 & 37.04 & 40.45 & 0.83 & 0.99 & 0.90 \\
\hline$T_{18}-S_{2} L_{3} E_{3}$ & 37.94 & 33.94 & 35.94 & 43.87 & 37.04 & 40.45 & 0.86 & 0.92 & 0.88 \\
\hline $\begin{array}{l}T_{19} \text {-Check basin } \\
\text { irrigation }\end{array}$ & 35.31 & 27.61 & 31.46 & 61.30 & 59.38 & 60.34 & 0.58 & 0.46 & 0.52 \\
\hline
\end{tabular}


Fig.1 Irrigation water use efficiency under different irrigation methods at pooled mean

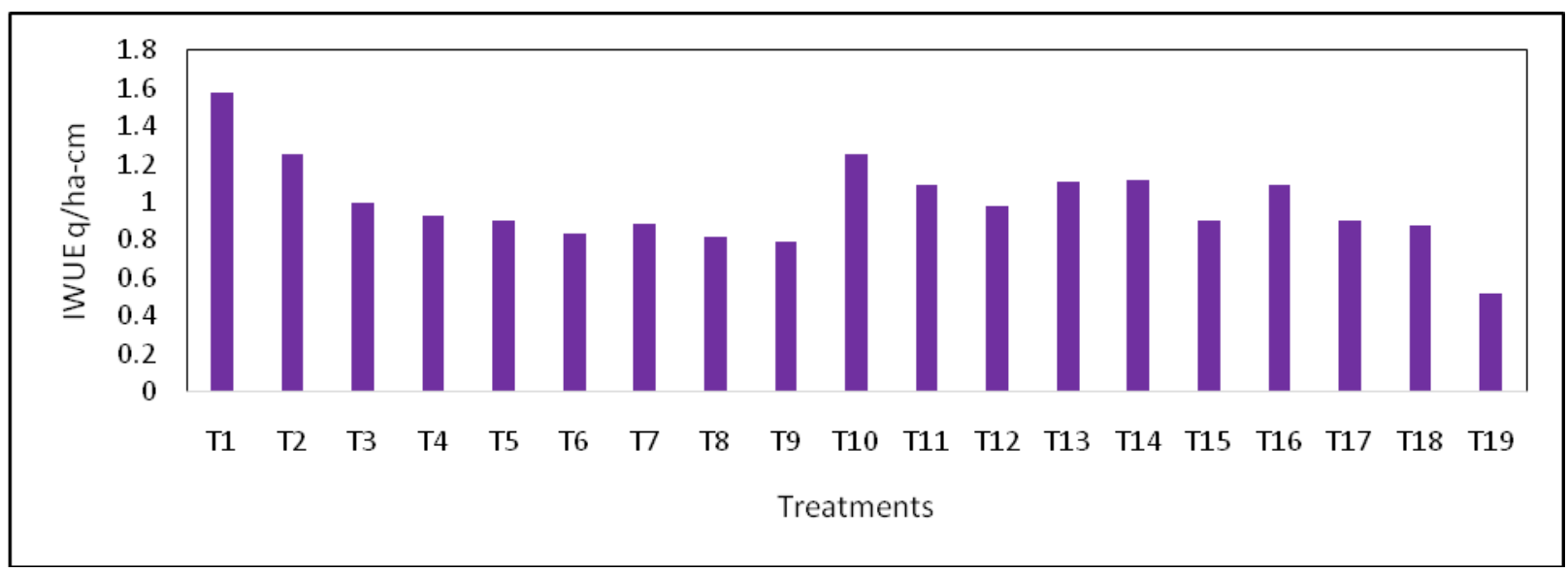

\section{Irrigation water use efficiency}

Total water requirement of wheat under different combinations of lateral and emitter spacings in surface and subsurface drip irrigation method and check basin irrigation method presented in Table 4.

Total water requirement of wheat was found highest in check basin method of irrigation i.e. 61.30 ha-cm, 59.38 ha-cm and 60.34 ha-cm during 2016-17, 2017-18 and pooled mean respectively. Lowest water requirement was found in surface and subsurface drip irrigation method i.e. 43.87 ha-cm, 37.04 ha-cm and 40.45 ha-cm during $2016-17,2017-18$ and pooled mean respectively. Therefore saving of irrigation water in surface and subsurface drip irrigation was found to the extent of $28.43 \%$, $37.62 \%$ and $32.96 \%$ during $2016-17,2017-18$ and pooled mean respectively as shown in Table 4.

Treatment combination $\mathrm{T}_{1}-\mathrm{S}_{1} \mathrm{~L}_{1} \mathrm{E}_{1}$ (surface drip irrigation method with 60 cmlateral spacing and $20 \mathrm{~cm}$ emitter spacing) recorded highest irrigation water use efficiency (1.58) followed by $T_{10^{-}}-S_{2} L_{1} E_{1}$ subsurface drip irrigation with 60 $\mathrm{cm}$ lateral spacing and $20 \mathrm{~cm}$ emitter spacing (1.25). Lowest irrigation water use efficiency was recorded in check basin irrigation method (0.52). Figure 1 shows that water use efficiency decreases as lateral and emitter spacing increases and is found minimum in check basin irrigation method. From the results it reveals that drip irrigation can save maximum amount of irrigation water with increasing yield of wheat crop.

These results are confirmation with those results obtained by Arafa et al., (2009), Liao et al., (2009), Chouhan et al., (2015) and Rao et al., (2016).

Results of present study suggest that adoption of drip irrigation saves a substantial amount of water as well a increase in yield of wheat crop. Main conclusion can be drawn as follows:

Total water requirement of wheat was found to be $404.5 \mathrm{~mm}$ (40.45 ha-cm) under surface and subsurface drip irrigation method; whereas it was found to be $603.4 \mathrm{~mm}(60.34 \mathrm{ha}-\mathrm{cm})$ in check basin method of irrigation; which results in saving of water through drip irrigation methods

Growth and yield parameters were recorded significantly superior desirable growth and yield parameters. Whereas, check basin irrigation method recorded lower growth and yield parameter as compared to the surface and subsurface drip irrigation method

Lateral spacing of $60 \mathrm{~cm}$ recorded significantly highest yield of wheat as compared to $80 \mathrm{~cm}$ and $100 \mathrm{~cm}$ lateral spacings. Similarly emitter 
spacing of $20 \mathrm{~cm}$ recorded significantly highest yield of wheat as compared to $30 \mathrm{~cm}$ and $40 \mathrm{~cm}$ emitter spacings, whereas combination of $60 \mathrm{~cm}$ lateral spacing and $20 \mathrm{~cm}$ emitter spacing recorded highest grain yield of wheat as compared to other combinations of lateral and emitter spacings.

Grain yield obtained in surface and subsurface drip irrigation methods was found statistically at par, but higher than check basin method of irrigation.

Highest irrigation water use efficiency was recorded in the combination of surface drip irrigation method with $60 \mathrm{~cm}$ lateral spacing and $20 \mathrm{~cm}$ emitter spacing.

Considering the performance of surface drip irrigation system with $60 \mathrm{~cm}$ lateral spacing and $20 \mathrm{~cm}$ emitter spacing this combination can be adopted by the farmers for commercial cultivation of wheat crop for getting higher production with saving of $32.96 \%$ water and there by maximum net monetary returns.

\section{Acknowledgement}

Authors wish to acknowledge Jain Hi-Tech Agri. Institute, Jain Irrigation Systems Ltd., Jalgaon, Maharashtra, for providing necessary facilities during the course of investigation

\section{References}

Arafa Y E, Essam AW, Hazem E M.2009. Maximizing water use efficiency in wheat yields based on drip irrigation systems. Australian $\mathrm{J}$ of Basic and Applied Sci. 3(2): 790-796.

Chouhan S, Awasthi M K and Nema R K. 2015. Studies on water productivity and yield responses of wheat based on drip irrigation systems in clay loam soil. Indian J. Sci. and Technol, 8: 650-54.

Dilip H and Madakini.1993 Micro irrigation An advanced technique on sugarcane. National Workshop on Micro Irrigation Techniques in Sugarcane. Vasantada Sugar Institute. 4-7

Hemlata N. 2015.Effect of drip irrigation and establishment methods on productivity, water use and economics of summer rice, Ph.D Thesis, Dept of Agronomy, College of Agriculture Indira Gandhi Krishi Vishwavidyalaya.

Liao L, Zhang L, and Bengtsson L. 2008.Soil moisture variation and water consumption of spring wheat and their effects on crop yield under drip irrigation. Irri and Drain Sys. 22: 253-270

Michael AM. 2008. Irrigation Theory and practice, Vikas Publishing House Pvt. ltd, New Delhi.

Rao K V R, Bajpai A, Gangwar S, Chourasia L and Soni K. 2016.Maximising water productivity of wheat crop by adopting drip irrigation. Res. on Crops. 17(1): 163168.

Tiwari KN, Mal PK, Sing RL and Chattopadhyay 1998 A Response of okra to drip irrigation under mulch and nonmulched condition. Agric Water Management.38, 91-102

Wang, J, Xu, C, Gao, S., Han, X. and Ju, D. 2013a. Effects of water and nitrogen utilized by means of dripping on growth of root and canopy and matter distribution in spring wheat. Adv. J. Food Sci. \& Technol. 5: 474-81.

Wang, J., Xu, C., Gao, S., Han, X. and Ju, D. 2013. Effect of water amounts applied with drip irrigation on water consumption characteristics and yield of spring wheat in Xinjiang. Adv. J. Food Sci. \& Technol, 2013.

\section{How to cite this article:}

Lokhande, J.N., M.M. Deshmukh, Bal Krishna and Wadatkar, S.B. 2019. Maximizing Yield and Water Use Efficiency of Wheat Crop Using Drip Irrigation Systems. Int.J.Curr.Microbiol.App.Sci. 8(07): 2647-2655. doi: https://doi.org/10.20546/ijcmas.2019.807.326 